\title{
The Effects of Fe, Mn and Zn Foliar Application on Yield, Ash and Protein Percentage of Forage Sorghum in Climatic Condition of Esfahan
}

\author{
Ali Soleymani ${ }^{1} \&$ Mohamad Hesam Shahrajabian ${ }^{1}$ \\ ${ }^{1}$ Department of Agronomy and Plant Breeding, Khorasgan (Esfahan) Branch, Islamic Azad University, \\ Esfahan, Iran \\ Correspondence: Ali Soleymani, Department of Agronomy and Plant Breeding, Khorasgan (Esfahan) Branch, \\ Islamic Azad University, Esfahan, PO box 81595-158, Iran. E-mail: a_Soleymani@khuisf.ac.ir
}

Received: March 1, 2012

Accepted: March 28, 2012 Online Published: June 13, 2012

doi:10.5539/ijb.v4n3p92

URL: http://dx.doi.org/10.5539/ijb.v4n3p92

\begin{abstract}
Improving forage yield and quality remains a major concern of the producer. Among the various ways of supplying nutrient to the crops, the efficient utilization of nutrients by the plants is made through foliar application. Foliar application had significant effect on plant height, the number of leaf, the number of tiller, LAI, fresh forage yield, dry leaf yield, dry stem yield, total dry yield, dry leaf weight/dry stem weight ration and ash percentage. Application methods of micronutrients are very important to attain the best absorption. The results of this study demonstrated that, $\mathrm{Fe}, \mathrm{Zn}$ and $\mathrm{Mn}$ had positive effect on yield and quality of forage sorghum. The highest plant height, LAI, Fresh forage yield, dry leaf and stem yield, total dry yield and dry leaf weight/dry stem weight was obtained in $\mathrm{Zn}+\mathrm{Fe}+\mathrm{Mn}$ application. The highest number of tiller was related to combination of $\mathrm{Zn}$ and $\mathrm{Mn}$. The maximum ash percentage and appropriate protein percentage also was achieved in application of $\mathrm{Zn}+\mathrm{Fe}+\mathrm{Mn}$. So, on the basis of the results, it seems that application $\mathrm{Zn}+\mathrm{Fe}+\mathrm{Mn}$ was suitable to gain high forage yield and gain to high quality.
\end{abstract}

Keywords: foliar application, yield, ash, protein, forage sorghum

\section{Introduction}

Sorghum (Sorghum bicolor (L.) Moench) is a major cereal food crop in many parts of the world (Shahrajabian et al., 2011). It is becoming an increasingly important forage crop in many regions of the world (Kasozi et al., 2005; Carmi et al., 2006). Zink extracts a great influence on basic plant life processes, such as (i) nitrogen metabolism, uptake of nitrogen and protein quality; (ii) photosynthesis-chlorophyll synthesis, carbon anhydrase activity; (iii) resistance to abiotic and biotic stresses protection against oxidative damage (Alloway, 2004; Cakmak, 2008; Potarzychi \& Grzebisz, 2009; Tekale et al., 2009). Zink also plays an important role in the production of biomass (Kaya \& Higgs, 2002; Cakmak, 2008). Iron plays essential roles in the metabolism of chlorophylls (Bybordu \& Mamedov, 2010). Kakade et al. (2009) noted that the application of $\mathrm{Fe}$ and $\mathrm{Zn}$ give maximum number of flowers, weight and yield of flowers as compared to control. Hebbern et al. (2005), Mirzapor and Khoshgoftar (2006), Chatterjee and Khurana (2007), Fernandes et al. (2007) and Wissuwa et al. (2008) concluded the positive effects of $\mathrm{Zn}$ and $\mathrm{Fe}$ on yield, yield components and chemical compositions of plant. Magnesium $(\mathrm{Mg})$ is an essential macro-element for plant growth (Trolove et al., 2008). Magnesium deficiency can impair export of photosynthate from leaves (Hermans, 2004), and reduces photosynthetic efficiency (Skinner \& Matthews, 1990). Recent studies research had show that a small amount of nutrients, particularly $\mathrm{Zn}, \mathrm{Fe}$ and $\mathrm{Mn}$ applied by foliar spraying increases significantly the yield of crops (Sarkar et al., 2007; Wissuwa et al., 2008; Bybordu \& Mamedov, 2010; Sajedi, 2010). It was documented that zinc foliar application is a simple way for making quick correction of plant nutritional status, as reported for wheat (Erenoglu et al., 2002) and maize (Grzebisz et al., 2008). World health organization reported deficiencies of $\mathrm{Zn}$ and $\mathrm{Fe}$ in human population of developing countries. Shahrajabian et al. (2011) concluded that the number of tillers per plant ranged between 1.889 and 3.444. In their experiment the maximum number of leaves per plant and stem diameter was 11.38 and $21.42 \mathrm{~mm}$, respectively. However, to the best of our knowledge, information regarding application method efficiency of $\mathrm{Zn}$, Fe and $\mathrm{Mn}$ on yield and yield components of forage sorghum is not available. Therefore, the purpose of this research is to understand the effects of application of micronutrients as foliar application on forage sorghum. 


\section{Materials and Methods}

This research was done at Research Farm, Faculty of Agriculture, Islamic Azad University, Khorasgan Branch (Esfahan) (latitude $32^{\circ} 40^{\prime} \mathrm{N}$, longitude $51^{\circ} 58^{\prime} \mathrm{E}$, and $1570 \mathrm{~m}$ elevation) in 2010 . Soil Texture was silt clay with soil $\mathrm{pH}$ of 7.95 at $0-30 \mathrm{~cm}$ and 8 at $30-60 \mathrm{~cm}$. EC was 1.9 and 1.6 at $0-30$ and $30-60 \mathrm{~cm}$, respectively. A randomized complete block design with four replications were used. Foliar application treatments included control treatment (without using any fertilizer) (T1), Fe (12\%) (T4), Zn (10\%) (T3), Mn (5\%) (T4), Fe+Zn (T5), $\mathrm{Fe}+\mathrm{Mn}(\mathrm{T} 6), \mathrm{Zn}+\mathrm{Mn}$ (T7) and $\mathrm{Zn}+\mathrm{Fe}+\mathrm{Mn}$ (T8). The soil preparation consisted of mouldboard ploughing followed by discing and smoothing with a land leveler. Ditches were prepared separately for each replication. Ditches were prepared separately for each replication. In this experiment, hybrid of forage sorghum, namely, Speed feed was used. Previous crop was barley and harvested on 15th June, and forage sorghum seeds were sown on 20th June with skillful workers. Application of nitrogen fertilizer was done in two stage, (i) $150 \mathrm{~kg}$ per ha was used before plantation and (ii) $80 \mathrm{~kg} \mathrm{~N}$ per ha was applied 45 days after plantation. The source of nitrogen fertilizer was urea. According to soil analysis and high amount of $\mathrm{P}$ and $\mathrm{K}, \mathrm{P}$ and $\mathrm{K}$ fertilizers were not used. For sorghum, atrazine at $1.3 \mathrm{~kg}$ a. i./ha were applied within a day after planting to control post emergence of weeds. Also, weeds were controlled by hoe weeding. The first irrigation was done immediately after sowing and the other irrigation intervals were done according to plant's requirement (10 days). Each experimental plot had six rows, the length and width of each plot was 4 and $3 \mathrm{~m}$, respectively. The distance between rows were 75 $\mathrm{cm}$. Rows number 1, 4, 6 and also upto $50 \mathrm{~cm}$, primer and edge lines were discarded from sampling. Rows number 2 and 3 were used for final sampling. For better irrigation, $2 \mathrm{~m}$ distances between main and sub plots and also each plot were designed. For evaluating of forage parameters in one cutting, 10 samples were harvested. After determination of fresh forage yield, plants were divided into separate organs and dried at $60^{\circ} \mathrm{C}$ for $96 \mathrm{~h}$ in an aerated oven. Ash content determined by incinerating the samples in a muffle furnace at $550{ }^{\circ} \mathrm{C}$ for $4 \mathrm{~h}$. Phosphorus estimated by colorimetric method (Badrzadeh et al., 2009). Dry matter yield of crops considered for comparison of yield production of the treatments. The amount of nitrogen calculated by Kjeldahl analysis from dry and ground samples, and then nitrogen will be multiply by 6.25 to determine protein content (Fallah \& Tadayyon, 2009). Data were subjected to analysis of variance (ANOVA) using statistical analysis system, followed by Duncan's multiple range test and differences were considered significant at $\mathrm{P}<0.05$ by MSTAT-C software.

\section{Results and Discussion}

The results revolved that all experimental characteristics expect of stem diameter, the number of leaf and protein percentage were significantly influenced by fertilizer foliar application. The highest plant height was related to foliar application of $\mathrm{Zn}+\mathrm{Fe}+\mathrm{Mn}(\mathrm{T} 8)(208 \mathrm{~cm})$. This treatment had significant difference with all treatments, expect of $\mathrm{Zn}+\mathrm{Mn}(\mathrm{T} 7), \mathrm{Fe}+\mathrm{Mn}$ (T6) and $\mathrm{Fe}+\mathrm{Zn}$ foliar application (T5). The lowest plant height was achieved in control treatment (T1) $(179 \mathrm{~cm})$ (Table 1). Highest plant height is a good agronomical management to achieve more biomass in forage crops (Shahrajabian et al., 2011). There were no significant differences in number of leaf between foliar application treatments, but the highest number of leas was related to $\mathrm{Zn}+\mathrm{Fe}+\mathrm{Mn}$ foliar application (T8). The highest stem diameter was obtained in Fe foliar application (T2) $(2.80 \mathrm{~cm})$, but all differences between treatments were not significant. Application of $\mathrm{Zn}+\mathrm{Mn}$ (T7) had obtained the highest number of tiller (1.8), but this treatment had no significant difference with T1 and T6. The minimum one also achieved in T8 (1.2). The maximum and the minimum LAI was obtained in $\mathrm{Zn}+\mathrm{Fe}+\mathrm{Mn}$ (T8) (8.06) and control treatment (T1) (6.7), respectively. T8 had significant differences in LAI with T7, T6, T5, T4, T3 and T2 (Table 1). When the economical aim is production of forage crops, suitable leaf area index (LAI) besides high plant height is so important (Shahrajabian et al., 2011). Application of $\mathrm{Zn}+\mathrm{Mn}+\mathrm{Fe}$ foliar application (T8) give the maximum fresh forage yield (125.2 t/ha), and differences between T8 and all other experimental treatments were significant. Shahrajabian et al. (2011) reported that the highest fresh yield in forage sorghum was $138.4 \mathrm{t} / \mathrm{ha}$. Ravi et al. (2010) indicated that combination of Fe and Zn foliar spray recorded the highest yield on safflower. T8 had obtained the highest dry leaf $(6.1 \mathrm{t} / \mathrm{ha})$ and dry stem yield $(6.0 \mathrm{t} / \mathrm{ha})$. T8 had no significant difference in dry leaf yield and dry stem yield with $\mathrm{T} 3$ and $\mathrm{T} 5$, respectively. The lowest dry leaf yield and dry stem yield was related to T2 (3.9 t/ha), and T2 (4.3 t/ha), respectively. Toader et al. (2010) also reported that, in the case of an appropriate soil fertilization, the effect of foliar fertilization ensured at maximum parameters of efficiency. The maximum total dry yield was $12.2 \mathrm{t} / \mathrm{ha}$ and achieved in $\mathrm{Zn}+\mathrm{Fe}+\mathrm{Mn}$ foliar application (T8) and it had significance difference with T1, T2, T3, T4 and T7 (Table 2). Potarzycki and Grzebisz (2009) reported that yield forming effect of zink fertilizer revealed via improvement of yield structure elements. Thakare et al. (2005) also reported that sorghum can grow well and produce high biomass in addition to grain under dry conditions. The highest and the lowest dry leaf weight/dry stem weight was obtained in application of T8 $(1.0 \%)$ and T2 $(0.78 \%)$, respectively. This 
ratio is one of the main character that revealed the high quality of forage crops (Shahrajabian et al., 2011). T8 and $\mathrm{T} 1 \mathrm{had}$ obtained the highest $(13.3 \%)$ and the lowest (12.1\%) ash percentage, respectively. T8 had no significant differences with T7, T6 and T5, respectively. Yvin and Dufils (2010) and Kumar et al. (2011) concluded that the quality of plants can be influenced directly by foliar application. Shahrajabian et al. (2011) reported that the highest dry forage yield in forage sorghum was $11.12 \mathrm{t} / \mathrm{ha}$. There were no significant differences in protein percentage between treatments, but the maximum one was related to T3 (12.9\%) (Table 2). Chemical fertilizes play a dominant role in agricultural development (Machado et al., 2008). Understanding of forage quality content in plants is useful for determining forage plant capacity to achieve higher animal performance (Badrzadeh et al., 2008; Assadi \& Khoshnood Yazdi, 2011).

Table 1. Mean comparison for plant height $(\mathrm{cm})$, stem diameter $(\mathrm{cm})$, the number of tiller, LAI, fresh forage yield ( $(\mathrm{h} / \mathrm{ha})$, dry leaf yield $(\mathrm{t} / \mathrm{ha})$ and dry stem yield ( $\mathrm{t} / \mathrm{ha})$

\begin{tabular}{ccccccccc}
\hline Treatment & $\begin{array}{c}\text { Plant } \\
\text { height }\end{array}$ & $\begin{array}{c}\text { The } \\
\text { number } \\
\text { of leaf }\end{array}$ & $\begin{array}{c}\text { Stem } \\
\text { diameter }\end{array}$ & $\begin{array}{c}\text { The } \\
\text { number } \\
\text { of tiller }\end{array}$ & LAI & $\begin{array}{c}\text { Fresh } \\
\text { forage } \\
\text { yield }\end{array}$ & $\begin{array}{c}\text { Dry leaf } \\
\text { yield }\end{array}$ & $\begin{array}{c}\text { Dry } \\
\text { stem } \\
\text { yield }\end{array}$ \\
\hline T1 & $179 \mathrm{bc}$ & $10.15 \mathrm{a}$ & $2.48 \mathrm{ab}$ & $1.63 \mathrm{a}$ & $6.7 \mathrm{~d}$ & $50.5 \mathrm{~d}$ & $4.0 \mathrm{f}$ & 4.6 \\
$\mathrm{~T} 2$ & $180 \mathrm{bc}$ & $9.7 \mathrm{a}$ & $2.80 \mathrm{~b}$ & $1.6 \mathrm{~b}$ & $7.3 \mathrm{bc}$ & $89.4 \mathrm{~d}$ & $3.9 \mathrm{f}$ & 4.3 \\
$\mathrm{~T} 3$ & $184 \mathrm{bc}$ & $10.16 \mathrm{a}$ & $2.2 \mathrm{~cd}$ & $1.7 \mathrm{~b}$ & $7.7 \mathrm{ab}$ & $89.6 \mathrm{~d}$ & $5.5 \mathrm{ab}$ & $5.5 \mathrm{bc}$ \\
$\mathrm{T} 4$ & $164 \mathrm{bc}$ & $10.2 \mathrm{a}$ & $2.4 \mathrm{ab}$ & $1.2 \mathrm{bc}$ & $7.2 \mathrm{c}$ & $99.7 \mathrm{c}$ & $4.6 \mathrm{e}$ & $5.1 \mathrm{def}$ \\
$\mathrm{T} 5$ & $196 \mathrm{ab}$ & $9.05 \mathrm{a}$ & $2.17 \mathrm{~cd}$ & $1.3 \mathrm{bc}$ & $7.2 \mathrm{ab}$ & $115.9 \mathrm{~b}$ & $5.5 \mathrm{~b}$ & $6.0 \mathrm{ab}$ \\
$\mathrm{T} 6$ & $193 \mathrm{ab}$ & $10.19 \mathrm{a}$ & $2.27 \mathrm{bc}$ & $1.77 \mathrm{a}$ & $7.3 \mathrm{bc}$ & $116.9 \mathrm{~b}$ & $5.5 \mathrm{~cd}$ & $5.3 \mathrm{bc}$ \\
$\mathrm{T} 7$ & $192 \mathrm{ab}$ & $9.70 \mathrm{a}$ & $2.21 \mathrm{~cd}$ & $1.8 \mathrm{a}$ & $7.7 \mathrm{bc}$ & $119.3 \mathrm{~b}$ & $5.2 \mathrm{~cd}$ & $5.5 \mathrm{bc}$ \\
$\mathrm{T} 8$ & $208 \mathrm{a}$ & $10.3 \mathrm{a}$ & $2.08 \mathrm{~d}$ & $1.2 \mathrm{bc}$ & $8.06 \mathrm{~b}$ & $125.2 \mathrm{a}$ & $6.1 \mathrm{a}$ & $6.2 \mathrm{a}$ \\
\hline
\end{tabular}

Common letters within each column do not differ significantly.

Table 2. Mean comparison for dry forage yield (t/ha), dry leaf weight/dry stem weight ratio, ash percentage (\%) and protein percentage $(\%)$

\begin{tabular}{ccccc}
\hline Treatment & Total dry yield & $\begin{array}{c}\text { Dry leaf } \\
\text { weight/dry stem } \\
\text { weight }\end{array}$ & Ash percentage & Protein percentage \\
\hline $\mathrm{T} 1$ & $8.6 \mathrm{~d}$ & $0.88 \mathrm{~d}$ & $12.0 \mathrm{~d}$ & $12.0 \mathrm{a}$ \\
$\mathrm{T} 2$ & $8.4 \mathrm{~d}$ & $0.78 \mathrm{~d}$ & $12.8 \mathrm{~cd}$ & $12.1 \mathrm{a}$ \\
$\mathrm{T} 3$ & $8.6 \mathrm{~d}$ & $0.96 \mathrm{bc}$ & $12.6 \mathrm{~cd}$ & $12.9 \mathrm{ab}$ \\
$\mathrm{T} 4$ & $9.7 \mathrm{c}$ & $0.92 \mathrm{c}$ & $12.9 \mathrm{c}$ & $11.7 \mathrm{a}$ \\
$\mathrm{T} 5$ & $11.9 \mathrm{a}$ & $0.99 \mathrm{ab}$ & $13.2 \mathrm{ab}$ & $12.5 \mathrm{a}$ \\
$\mathrm{T} 6$ & $11.9 \mathrm{a}$ & $0.93 \mathrm{c}$ & $13.1 \mathrm{ab}$ & $11.9 \mathrm{a}$ \\
$\mathrm{T} 7$ & $11.3 \mathrm{~b}$ & $0.95 \mathrm{c}$ & $12.1 \mathrm{a}$ & $12.1 \mathrm{a}$ \\
$\mathrm{T} 8$ & $12.2 \mathrm{a}$ & $1.0 \mathrm{a}$ & $13.3 \mathrm{a}$ & $12.0 \mathrm{a}$ \\
\hline
\end{tabular}

Common letters within each column do not differ significantly.

\section{Conclusions}

Micronutrients are required by plants in minute quantities, although these are very effective in regulating plant growth as they form a part of the enzyme system and thus regulate plant life (Pathak et al., 2011). Application methods of micronutrients are very important to attain the best absorption. The results of this study demonstrated that, $\mathrm{Fe}, \mathrm{Zn}$ and $\mathrm{Mn}$ had positive effect on yield and quality of forage sorghum. The highest plant height, LAI, Fresh forage yield, dry leaf and stem yield, total dry yield and dry leaf weight/dry stem weight was obtained in $\mathrm{Zn}+\mathrm{Fe}+\mathrm{Mn}$ application. By managing of agronomic practice, quality of forage will be influenced (Dahmardeh et 
al., 2009). The maximum ash percentage and appropriate protein percentage also was achieved in application of $\mathrm{Zn}+\mathrm{Fe}+\mathrm{Mn}$. The nutrient value of plant composition and feed quality is necessary for efficient animal production (Asaadi \& Khoshnood Yazdi, 2011). So, on the basis of the results, it seems that application $\mathrm{Zn}+\mathrm{Fe}+\mathrm{Mn}$ was suitable to gain high forage yield and gain to high quality.

\section{References}

Alloway, B. (2004). Zink in soils and crop nutrition. Areas of the World with Zinc Deficiency Problems. Available at: http://www.zinc-crops.org/Crops/Alloway-all

Asaadi, A. M., \& Khoshnood Yazdi, A. (2011). Phenological stage effects of forage quality of four forbs species. Journal of Food, Agriculture and Environment, 9(2), 380-384.

Badrzadeh, M., Zaragarzadeh, F., \& Esmaielpour, B. (2008). Chemical composition of some forage Vicia spp. in Iran. Journal of Food, Agriculture and Environment, 6(2), 178-180.

Bybordi, A., \& Mamedov, G. (2010). Evaluation of application methods efficiency of zinc and iron for canola (Brassica napus L.). Not Sci Biol., 2(1), 94-103.

Cakmak, I. (2008). Enrichment of cereal grains with zinc: agronomic or genetic biofortification? Plant and Soil, 302, 1-17. http://dx.doi.org/10.1007/s11104-007-9466-3

Carmi, A., Aharoni, Y., Edelstein, M., Umiel, N., Hagiladi, A., Yosef, E., Nikbacht, M., Zenou, A., \& Miron, J. (2006). Effects of irrigation and plant density on yield, composition and in vitro digestibility of a new forage sorghum variety, Tal, at two maturity stages. Animal Feed Science and Technology, 131, 120-132. http://dx.doi.org/10.1016/j.anifeedsci.2006.02.005

Chatterjee, C., \& Khurana, N. (2007). Zinc stress- induced changes in biochemical parameters and oil content of mustard. Commun. Soil Sci. Plant Anal., 38, 751-761. http://dx.doi.org/10.1080/00103620701220718

Dahmardeh, M., Ghanbari, A., Syasar, B., \& Ramrodi, M. (2009). Intercropping maize (Zea mays L.) and cow pea (Vigna unguiculata L.) as a whole-crop forage: Effects of planting ration and harvest time on forage yield and quality. Journal of Food, Agriculture and Environment, 7(2), 505-509.

Erenoglu, B., Nikolic, M., Romhold, V., \& Cakmak, I. (2002). Uptake and transport of foliar applied zinc $\left({ }^{65} \mathrm{Zn}\right)$ in bread and durum wheat cultivars differing in zink efficiency. Plant and Soil., 241, 251-257. http://dx.doi.org/10.1023/A:1016148925918

Fallah, S., \& Tadayyon, A. (2009). Effects of plant density and nitrogen rates on yield, nitrate and protein of silage maize. Electronic Journal of Crop Productivity (EJCP), 2(1), 105-121. (in Persian)

Fernandes, D. S., Soratto, R. P., Kulczynski, S. M., Biscaro, G. A., \& Dos Reis, C. J. (2007). Yield and physiological quality of common bean seeds as affected by manganese foliar application. Pesq. Agropec. Bras. Brasilia., 42, 419-426. http://dx.doi.org/10.1590/S0100-204X2007000300016

Grzebisz, W., Wronska, M., Diatta, J. B., \& Dullin, P. (2008). Effect of zinc foliar application at early stages of maize growth on patterns of nutrient and dry matter accumulation by the canopy. Part 1. Zinc uptake patterns and its redistribution among maize organs. Journal of Elementology., 13, 17-28.

Hebbern, C. A., Pedas, P., Schjoerring, J. K., Knudsen, L., \& Husted, S. (2005). Genotypic differences in manganese efficiency: field experiment with winter barley (Hordeum vulgars L.). Plant Soil, 272, 233-244. http://dx.doi.org/10.1007/s11104-004-5048-9

Hermans, C., Johnson, G. N., Strasser, R. J., \& Verbruggen, N. (2004). Physiological characterization of magnesium deficiency in sugar beet: acclimation to low magnesium differentially affects photosytems I and II. Planta, 220, 344-355. http://dx.doi.org/10.1007/s00425-004-1340-4

Kakade, D. K., Rajput, \& Joshi, K. I. (2009). Effect of foliar application of Fe and Zn on growth, flowering and yield of China aster (Callistephus chinensis L. Nees). The Asian Journal of Horticulture, 4(1), 138-140.

Kasozi, S. M., Bashaasha, B., \& Ochwoh, V. (2005). Economics of sorghum production and soil fertility management in Kabale Highlands, Uganda. Journal of Food, Agriculture and Environment, 3(3\&4), 105-109.

Kaya, C., \& Higgs, D. (2002). Response of tomato (Lycopersicon esculentum L.) cultivars to foliar application of zinc when grown in sand culture at low zinc. Sci. Hortic., 93, 53-64. http://dx.doi.org/10.1016/S0304-4238(01)00310-7

Kumar, J., Arya, K. C., \& Sidduqoue, M. Z. (2011). Effect of foliar application of $\mathrm{KNO}_{3}$ on growth, yield 
attributes, yield and economics of hirsutum cotton. J. Cotton Res. Dev., 25(1), 122-123.

Machado, R. M. A., Bryla, D. R., Verissimo, M. L., Sena, A. M., \& Oliveira, M. R. G. (2008). Nitrogen requirements for growth and early fruit development of drip-irrigated processing tomato (Lycopersicon esculentum Mill.) in Portugal. Journal of Food, Agriculture and Environment, 6(3\&4), 215-218.

Marsali, M. A., Angadi, S. V., \& Contreras- Govea, F. E. (2010). Dry matter yield and nutritive value of corn, forage sorghum, and BMR forage sorghum at different plant populations and nitrogen rates. Field Crops Research, 116, 52-57. http://dx.doi.org/10.1016/j.fcr.2009.11.009

Mirzapour, M. H., \& Khoshgoftar, A. H. (2006). Zinc application effects on yield and seed oil content of sunflower grown on a saline calcareous soil. J. Plant nutr., 29, 1719-1727. http://dx.doi.org/10.1080/01904160600897430

Pathak, M., Bauri, F. K., Misra, D. K., Bandyopadhyay, B., \& Chakraborty, K. (2011). Application of micronutrients on growth, yield and quality of banana. Journal of Crop and Weed, 7(1), 52-54.

Potarzycki, J., \& Grzebisz, W. (2009). Effect of zinc foliar application on grain yield of maize and its yielding components. Plant Soil Environ., 55(12), 519-527.

Ravi, S., Channal, H. T., \& Shailendra Kumar, G. (2010). Response of sulphur and micronutrients (Zn and Fe) on yield and available nutrients of safflower (Carthamus tinctorius L.). An Asian Journal of Soil Science, 5(2), 402-405.

Sajedi, N. A. (2010). Effect of nutrients foliar application on agrophysiological characteristics of maize under water deficit stress. Not Sci Biol., 2(3), 39-44.

Sarkar, D., Mandal, B., \& Kundu, M. C. (2007). Increasing use efficiency of boron fertilizers by rescheduling the time and methods of application for crops in India. Plant Soil, 301, 77-85. http://dx.doi.org/10.1007/s11104-007-9423-1

Shahrajabian, M. H., Soleymani, A., \& Naranjani, L. (2011). Grain yield and forage characteristics of forage sorghum under different plant densities and nitrogen levels in second cropping after barley in Isfahan, Iran. Research on Crops, 12(1), 68-78.

Skinner, P. W., \& Matthews, M. A. (1990). A novel interaction of magnesium translocation with the supply of phosphorous to roots of grapevine (Vitis vinifera L.). Plant, Cell and Environment, 13, 821-826. http://dx.doi.org/10.1111/j.1365-3040.1990.tb01098.x

Tekale, R. P., Guhey, A., \& Agrawal, K. (2009). Impact of boron, zink and IAA on growth, dry matter accumulation and sink potential of pigeon pea (Cajanus Cajan L.). Agric. Sci. Digest., 29(4), 246-249.

Thakare, R., Bhongle, S. A., \& Somani, R. B. (2005). Biochemical properties of some elite sweet sorghum cultivars. Journal of Soils and Crops, 15(1), 136-138.

Toader, C., Rusu, M., Marghitas, M., \& Mihai, M. (2010). Foliar fertilization effect of supplementing the fertilization of the soil on the production of potato tubers. Bulletin UASVM Agriculture, 67(1), 279- 285.

Trolove, S. N., Wheeler, S., \& Spiers, A. (2008). A comparison of three methods of magnesium application to grapes. Agronomy New Zealand, 38, 69-76.

Wissuwa, M., Ismail, A. M., \& Graham, R. D. (2008). Rice grain zinc concentrations as affected by genotype native soil-zinc availability, and zinc fertilization. Plant Soil, 306, 37-48. http://dx.doi.org/10.1007/s11104-007-9368-4

Yvin, J. C., \& Dufils, A. (2010). Incidences of ferileader Elite foliar spray applications on the improvement of fruits quality and their conservation. Trials realized on Pink Lady Cripps Pink Cov. Journal of Horticulture, Forestry and Biotechnology, 14(3), 1-4. 